\title{
CONSIDERATIONS ON THE EFFECT OF ANTI-SANDFLY ANTIBODIES ON BIOLOGICAL PARAMETERS OF Lutzomyia longipalpis (LUTZ \& NEIVA, 1912) (DIPTERA: PSYCHODIDAE: PHLEBOTOMINAE)
}

\author{
VILELA, M. L. ${ }^{1}$, SOUZA, N. A. ${ }^{1}$, OLIVEIRA, S. M. P. ${ }^{1}$, COSTA-PINTO, D. ${ }^{2}$, \\ CABELLO, P. H. ${ }^{3}$, RANGEL E. F. ${ }^{1}$ and TRAUB-CSEKO, Y. M. ${ }^{2}$ \\ ${ }^{1}$ Laboratório de Transmissores de Leishmaniose, Departamento de Entomologia, Instituto Oswaldo Cruz - FIOCRUZ, \\ Av. Brasil, 4365, Manguinhos, Rio de Janeiro, RJ, Brazil \\ ${ }^{2}$ Laboratório de Biologia Molecular de Tripanosomatídeos e Flebotomíneos, \\ Departamento de Bioquímica e Biologia Molecular, Instituto Oswaldo Cruz - FIOCRUZ, \\ Av. Brasil, 4365, Manguinhos, Rio de Janeiro, RJ, Brazil \\ ${ }^{3}$ Laboratório de Genética Humana, Departamento de Genética, Instituto Oswaldo Cruz - FIOCRUZ, \\ Av. Brasil, 4365, Manguinhos, Rio de Janeiro, RJ, Brazil \\ Correspondence to: Maurício Luiz Vilela, Departamento de Entomologia, Instituto Oswaldo Cruz, FIOCRUZ, \\ Av. Brasil, 4365, Manguinhos, Rio de Janeiro, RJ, Brazil, e-mail: mvilela@ioc.fiocruz.br \\ Received February 21, 2003 - Accepted April 29, 2004 - Distributed February 28, 2006
}

(With 5 figures)

\begin{abstract}
The immunization of vertebrate hosts with vector components may be an alternative for the control of diseases transmitted by insects. In the present study we evaluated the effects of anti-sandfly antibodies on some of the biological parameters of female Lutzomyia longipalpis, a vector of visceral leishmaniasis. Rabbits were immunized with extracts of gut from blood-fed (GB) or sugar-fed (GS) females, carcass of sugar-fed (CS) or blood-fed (CB) females, and with repeated sandfly bites (BITE). Immune sera showed increased antibody titers compared to pre-immunized animals, and specific bands were detected by Western Blot. An analysis of biological parameters revealed a decline in fecundity in the group of females fed on rabbits immunized with GB and BITE. Longevity and mortality were studied in females with oviposition (parous) and without oviposition (nulliparous). Nulliparous females that fed on rabbits immunized with bites died in the highest percentage. A mortality analysis after egg laying revealed a peak on the fifth day in all the groups, but females fed on rabbit subjected to repeated bites showed a shift towards the third day.
\end{abstract}

Keywords: Lutzomyia longipalpis, anti-sandfly antibodies, sandfly biology.

\section{RESUMO}

\section{Considerações sobre o efeito de anticorpos antiflebótomos sobre parâmetros biológicos de Lutzomyia longipalpis (Lutz e Neiva, 1912) (Diptera: Psychodidae: Phlebotominae)}

A imunização de hospedeiros vertebrados com componentes derivados de vetores pode se constituir numa estratégia alternativa para o controle de doenças transmitidas por insetos. No presente estudo avaliamos o efeito de anticorpos antiflebótomos sobre alguns parâmetros biológicos de fêmeas de Lutzomyia longipalpis, vetor de leishmaniose visceral. Coelhos foram imunizados com extratos de tubos digestivos de fêmeas alimentadas com açúcar (GS), fêmeas alimentadas com sangue (GB), carcaças de fêmeas alimentadas com açúcar (CS) ou carcaças de fêmeas alimentadas com sangue (CB), e coelho imunizado por repetidas picadas de fêmeas de flebótomos (BITE). Os soros imunes de coelhos apresentaram títulos aumentados quando comparados com os soros pré-imunes, e bandas específicas foram detectadas por meio de Western Blot. A análise dos parâmetros biológicos revelou um decréscimo na fecundidade no grupo de fêmeas alimentadas em coelho imunizado com GB e BITE. A longevidade e a mortalidade foram estudadas em 
fêmeas com postura (paridas) e fêmeas sem postura (nulíparas). Fêmeas nulíparas que se alimentaram em coelho imunizado por repetidas picadas morreram em maior percentual. A análise da mortalidade, após a postura dos ovos, revelou um pico no quinto dia em todos os grupos, mas em fêmeas que se alimentaram em coelho submetido a repetidas picadas, foi antecipada para o terceiro dia.

Palavras-chave: Lutzomyia longipalpis, anticorpos antiflebótomos, biologia de flebótomos.

\section{INTRODUCTION}

In view of the wide prevalence of leishmaniasis throughout the world, the search for alternative control measures is of utmost importance. Nevertheless, due to the existence of many different species of leishmania, multiple clinical manifestations, and distinct species of sandflies adapted to various environmental conditions, control actions have not been efficient. Since natural breeding sites are difficult to identify in nature, vector control measures have been aimed mostly at the adult insect forms.

The injection into mammals of haematophagous vector extracts, or saliva components delivered through the bite, has been found to stimulate a wide spectrum of immune responses with the production of anti-vector antibodies (Almeida \& Billingsley 1998; Hatfield 1988; Ramasamy et al., 1988; 1992; Srikrishnaraj et al., 1993; Wikel, 1982). This approach could be an interesting alternative for the control of haematophagous arthropods or of the diseases transmitted by them, since it might affect not only vital processes in the insects' biological development, but also interfere with their vectorial capacity (Alger \& Cabrera, 1972; Lal et al., 1994; Ramasamy et al., 1990; Ramasamy \& Ramasamy, 1990; Sutherland \& Ewen, 1974).

The action of anti-sandfly antibodies against Phlebotomus duboscqi (Ingonga et al., 1996) and P. argentipes (Ghosh \& Mukhopadhyay, 1998) has been demonstrated to affect not only the insects' biology but also the host-parasite interaction. This paper presents the first studies of this kind on a New World sandfly, Lutzomyia longipalpis (Lutz \& Neiva, 1912), which plays an important role in the dissemination of visceral leishmaniasis in the American continents. The purpose of this work was to evaluate the influence of antibodies produced against extracts of females in different nutritional states and against saliva components on some of the sandfly's biological aspects.

\section{MATERIAL AND METHODS}

\section{Sandflies}

Specimens of L. longipalpis from an established colony maintained at the Department of Entomology, Oswaldo Cruz Institute were used in this study.

The sandflies were reared according to a modified version of the methodology described by Modi \& Tesh (1983) and Wermelinger et al., (1987).

\section{Preparation of extracts and immunizations}

Two groups of Lutzomyia longipalpis were used as a source of antigen. The first consisted of females fed on a sugar solution for a period up to $48 \mathrm{~h}$ after emergence, when they were dissected. The second group of females was fed with the sugar solution for the same period of time, and then fed on the internal face of a rabbit's ear. Dissection of these females was carried out $72 \mathrm{~h}$ after the blood meal. Both groups were dissected by separating the gut from the rest of the insect body. The dissected material was transferred to Eppendorf tubes containing $100 \mu \mathrm{L}$ of PBS (Phosphate Buffered Solution) at $\mathrm{pH} 7.4$, and named according to its origin: gut from females fed exclusively on sugar (GS), carcass (whole body after removal of gut) of females fed exclusively on sugar (CS), gut from females fed with sugar and rabbit blood (GB), carcass from females fed on sugar and rabbit blood (CB).

The rabbits employed in the study were bled before immunization through a cardiac punch to collect pre-immune serum.

The dissected materials (carcass or guts) were homogenized with a pestle and centrifuged for a few seconds. Rabbits were immunized subcutaneously, in various inoculation sites on the abdomen, using each product emulsified with Freund's complete adjuvant (Difco), in a final volume of $1 \mathrm{~mL}$. Two subsequent boosting immunizations were done 
with the same volume of antigen emulsified in Freund's incomplete adjuvant, at 10-day intervals. The control rabbit was inoculated with PBS and adjuvant, following the same protocol.

Immunization through repeated bites was done by exposing the rabbits to 100-120 females, according to the protocol shown in Fig. 1.

Ten days after the last immunization the rabbits were bled by cardiac punch for collection of their immune sera.

\section{Sandfly experiments}

To evaluate the effect of immunizations on the feeding process, fecundity and longevity of L. longipalpis females, a total of 1,128 specimens were employed. Ten days after the last immunization, the insects were fed on the rabbits for the first time. The subsequent tested female groups were fed on rabbits 16 and 25 days after immunization.

\section{ELISA and Western Blot}

The presence of anti-sandfly antibodies was evaluated through ELISA (enzyme-linked immunosorbent assay) and Western Blot. Prior to performing the ELISA, the protein concentration in the extracts was measured using a BioRad kit and following the manufacturer's instructions. Three hundred ng of protein in $100 \mu \mathrm{L}$ were placed in microplate wells and incubated overnight at $4{ }^{\circ} \mathrm{C}$. The plates were then washed with PBS and the wells were blocked with $200 \mu \mathrm{L} 5 \%$ lowfat milk in PBS for $1 \mathrm{~h}$. Test rabbit sera $(200 \mu \mathrm{L})$ were added, diluted to 1:100 and 1:500, and incubated overnight at $4{ }^{\circ} \mathrm{C}$. The wells were washed twice, the secondary antibody (goat anti-rabbit) conjugated with alkaline phosphatase and diluted to 1:2500 was added and the wells incubated at room temperature for $2 \mathrm{~h}$. Absorbance was read at $405 \mathrm{~nm}$.

For the Western Blot, tissues were homogenized in $60 \mu \mathrm{L}$ of PBS and $40 \mu \mathrm{L}$ of loading buffer were applied. These samples, $30 \mu \mathrm{L}$ of gut (equivalent to 9 females) and $15 \mu \mathrm{L}$ of carcass (equivalent to 4.5 females) were subjected to SDS-PAGE in $10 \%$ polyacrylamide gel, as described by Laemmli (1970). Proteins were transferred to nitrocellulose filters $(0.45 \mu \mathrm{m}$, Schleider \& Schuell $)$ at $100 \mathrm{~V}$ for approximately $1 \mathrm{~h}$ at $4{ }^{\circ} \mathrm{C}$. The membrane was stained with Ponceau-S for visualization of bands. Blocking was done with 5\% lowfat milk in PBS, $\mathrm{pH} 7.4$, for $1 \mathrm{~h}$ at room temperature with agitation. The primary antibody (1:500) in 5\% lowfat milk and $0.05 \%$ Tween 20 in PBS was incubated overnight at $4{ }^{\circ} \mathrm{C}$, under agitation. The membrane was then washed three times in PBS for 30 min under agitation. The secondary antibody (goat anti-rabbit) conjugated with alkaline phosphatase (Gibco BRL) was incubated in the same solution for $2 \mathrm{~h}$ at room temperature under agitation. After washing, the membranes were developed using the manufacturer's protocols (KPL Kirkegaard \& Perry).

\section{Statistical methods}

Statistical tests were employed in the analyses of the data. The median was used in the fecundity evaluation, since there was a large sample of eggs and asymmetric values. The number of eggs was evaluated through the Mann-Whitney and Kruskal Wallis non-parametric tests.

Survival curves (Kaplan-Meier estimate) were obtained by plotting the estimated survival probability, $\operatorname{Pr}(\mathrm{T}>\mathrm{t})$, and were used to analyze female mortality. The estimated survival probability

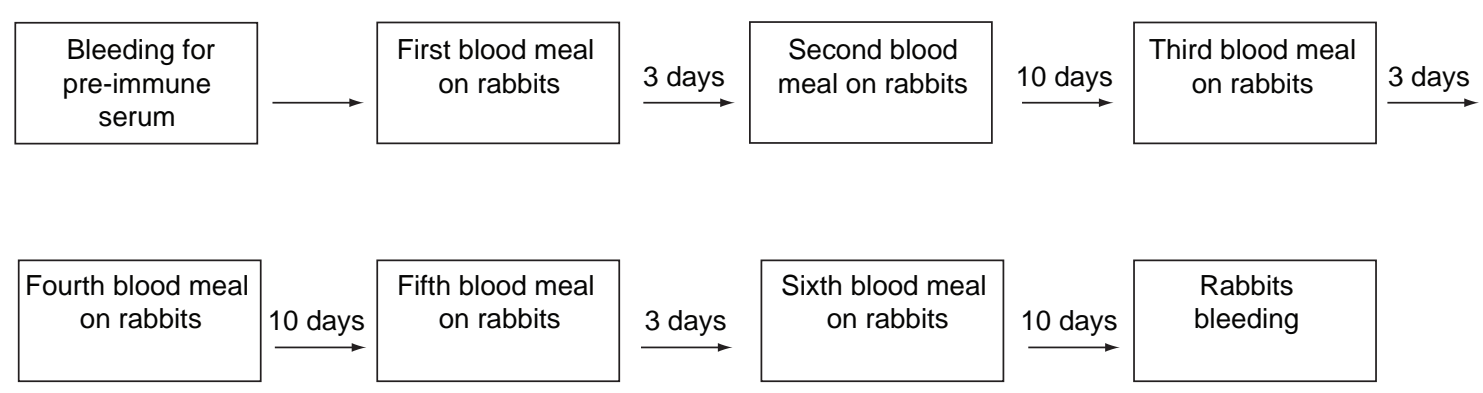

Fig. 1 - Schematic representation of rabbits exposed to successive bites by Lutzomyia longipalpis females. 
at the beginning of the experiment was calculated by the successive multiplication of the proportion of individuals under observation, the value for day zero being 1 . Differences among curves were determined through the Log-Rank or Mantel-Haenszel chi-squared tests and the level of significance of the test is given by: $\operatorname{Pr} \chi_{\mathrm{k}-1}^{2}$ variable (chi-squared with $\mathrm{k}-1$ degrees of freedom), where $\mathrm{k}$ is the number of groups whose survival experience is being compared. The results obtained from the comparison of the survival curves were tested based on critical values of the $\chi^{2}$ distribution, where the probability level $\mathrm{t}=0.05$.

\section{RESULTS}

\section{Analysis of sera}

The ELISA test revealed that the immune sera had increased antibody titers in all cases when compared with the pre-immune sera (results not shown). Good immune response was also demonstrated by the Western Blot tests. Strong specific bands were evident in all the immune sera tested (Fig. 2), while fewer very weak bands were seen with the pre-immune sera. Anti-GB and
anti-GS recognized basically the same prevalent bands, with a few differences. Similar results were detected with immune sera anti-CB and anti-CS, revealing many strong bands when compared with the pre-immune sera (results not shown).

\section{Effect of immune sera on biological parameters of L. longipalpis}

No differences were observed in relation to the success of first feeding among the groups fed on animals immunized with different extracts or BITE and the controls.

Two parameters were considered for oviposition: the number of females laying eggs and the number of eggs laid by females. Females fed on the animals immunized with GB or BITE laid the lowest median number of eggs (Fig. 3). Considering the number of eggs laid by females, significant differences were observed among all the groups of females $\left(\chi^{2}=33,414 ; p=0.00\right)$ when analyzed by the Kruskal-Wallis test, while GS and CONTROL groups showed the highest mean rank. Comparative evaluations among groups of females based on the Mann-Whitney test showed that extracts from GB groups displayed statistically

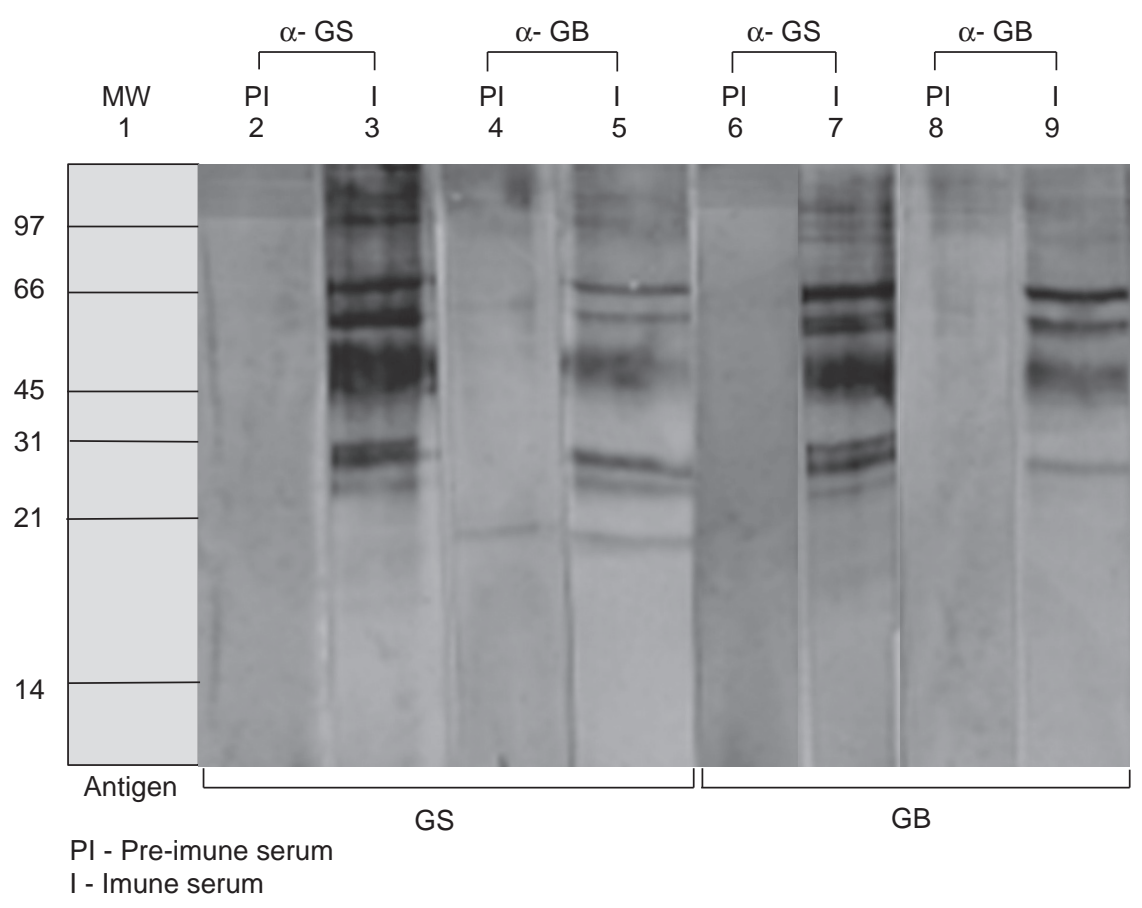

Fig. 2 - Western Blot of Lutzomyia longipalpis extracts. 


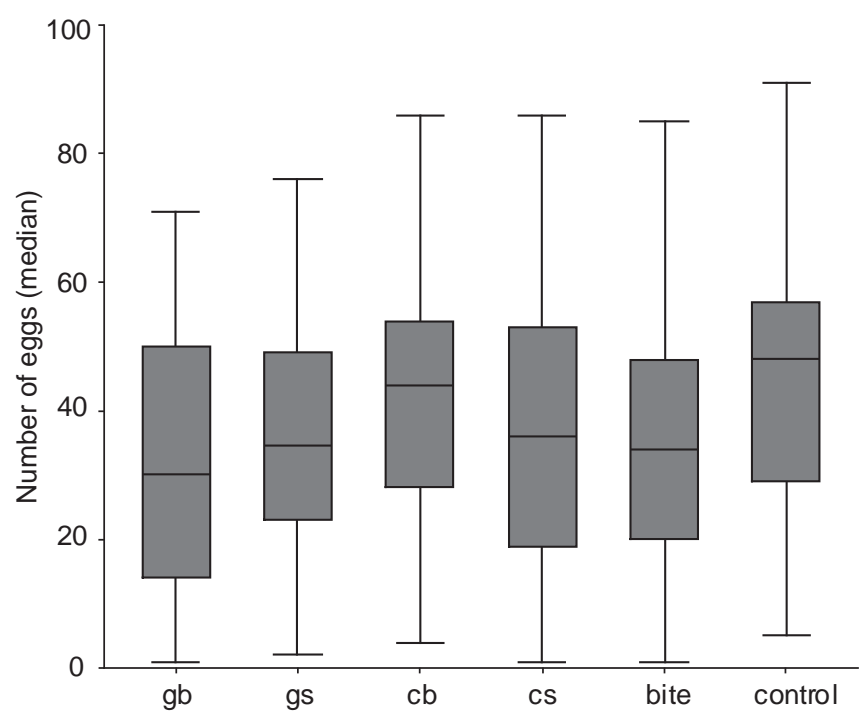

Fig. 3 - Eggs laid by Lutzomyia longipalpis females fed on rabbits immunized with sandfly extracts and bites.

significant differences $(\mathrm{p}=0.000)$ when compared with controls. A comparison of the number of eggs from the GB and GS groups indicated that sandflies fed on rabbits immunized against extracts from engorged females had lower oviposition $(\mathrm{p}=0.000)$ than did extracts from females fed on sugar. Similar evidence was seen in females fed on rabbits exposed to bites in relation to controls, suggesting that saliva components could interfere in egg laying $(p=0.000)$.

Mortality was considered concomitantly to oviposition by comparing the percentage of deaths of parous and nulliparous females on different days. Nulliparous females fed on rabbits exposed to repeated bites or immunized with GB showed the highest death rate (Fig. 4)

When the mortality of parous females was examined, the highest number of deaths was found to occur on the third and fifth post-feeding days in all the groups, but was more marked in the $\mathrm{CB}$ and BITE groups. The peak fell clearly on the fifth day in all the groups with the exception of BITE, which showed a shift towards the third day (Fig. 5).

Significant differences were seen when comparing the survival curves of all the females (parous and nulliparous) fed on rabbits immunized with extracts of sandflies. Females fed on rabbits immunized with GB showed the most significantly lower survival curve when compared with controls (Table 1).

\section{DISCUSSION}

Synthetic insecticides are still the most popular control method for hematophagous arthropods, even considering the development of resistance against some compounds (Consoli \& Lourenço-deOliveira, 1994). Strategies based on immunization of the vertebrate host with arthropod derived tissues or saliva components could be employed to interfere with vital aspects of the biological cycle of these vectors, and as an alternative approach to the existing control policies. The most successful case for the use of this approach in arthropod control was for the tick. Trager (1939) was the first to show the feasibility of inducing immunity by tick tissue injection. These initial results progressed to the identification of antigen candidates that are presently being employed in field immunization of cattle (Patarroyo et al., 2002).

This kind of approach to control leishmaniasis may offer some advantages over currently employed measures, either in relation to insecticides, which are restrictive when used continuously, or in patient therapy normally involving high levels of toxicity.

The long-term interest of studying antisandfly immunization employing gut tissues of L. longipalpis relies on our interest in investigating 


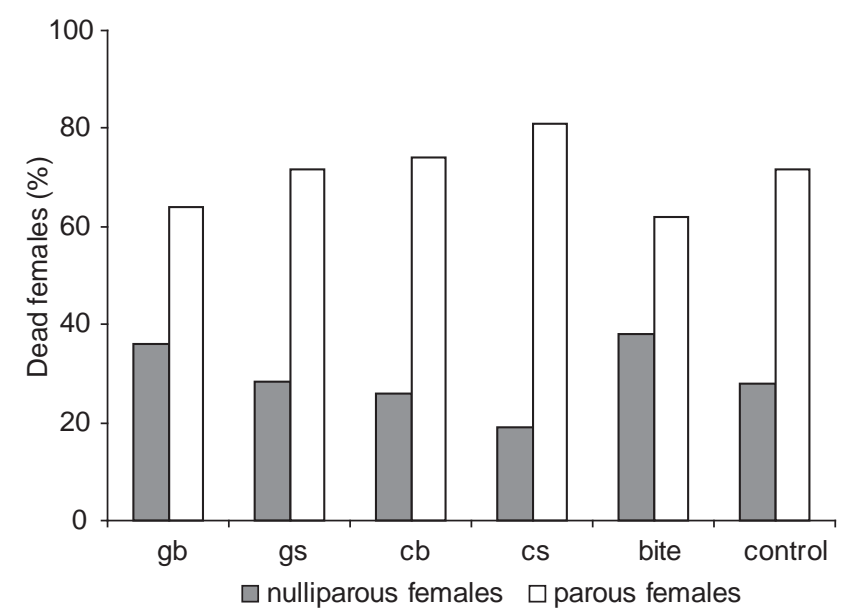

Fig. 4 - Mortality distribution of Lutzomyia longipalpis females fed on rabbits immunized with sandfly extracts or bites.

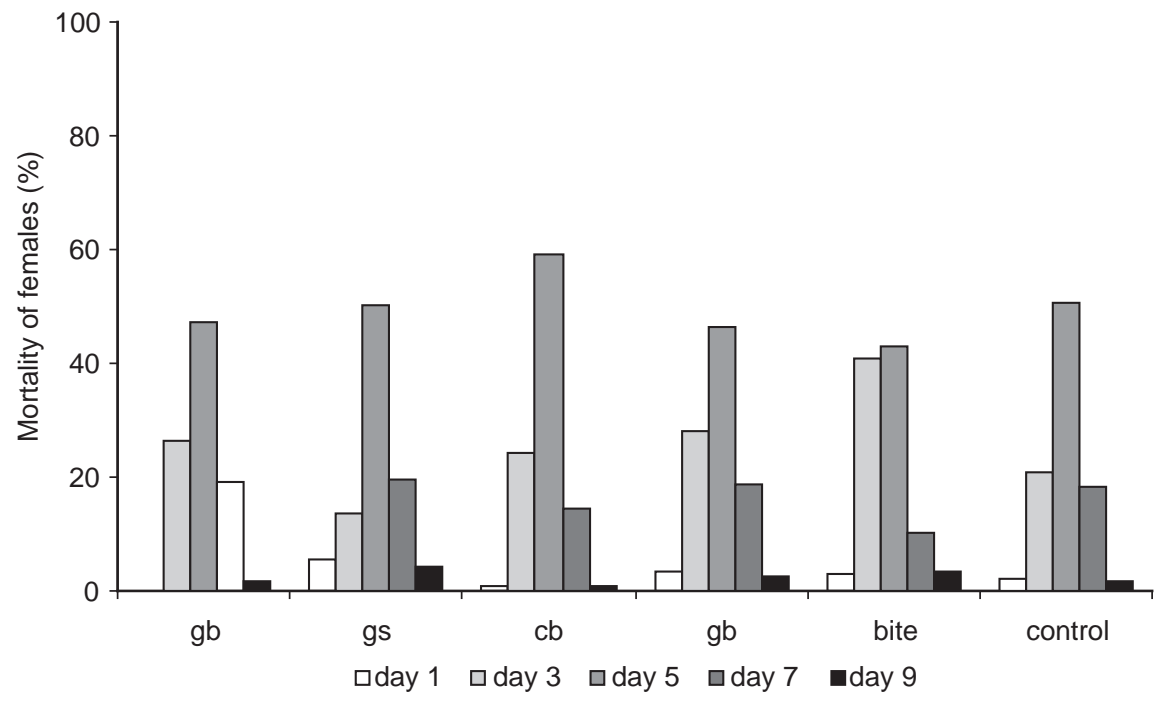

Fig. 5 - Mortality distribution of parous Lutzomyia longipalpis females fed on rabbits immunized with sandfly extracts or bites.

the possible effects of these antibodies on the parasite-insect vector interactions, considering the gut is the place where these interactions occur. On the other hand, sandfly saliva has been shown to play an important role in Leishmania infectivity (Belkaid et al., 1998).

Studies similar to the ones presented here were conducted employing sera of hamsters immunized with tissues of $P$. duboscqi (Ingonga et al., 1996), anti-gut antibodies were highest 2-3 weeks post-immunization, as compared to carcass, and significantly higher mortality and decreased egg production were seen in insects fed on immunized animals. High antibody titers were detected when hamsters were exposed to repeated bites of $P$. argentipes females, but not when they were immunized with carcasses devoid of salivary glands (Ghosh \& Mukhopadhyay, 1998). These authors observed not only higher mortality in females fed on animals subjected to repeated bites, but also inhibition of the development of leishmania in the gut of the sandfly vector. Other studies on mosquitoes also found reaction against 
TABLE 1

Comparison of survival curves of Lutzomyia longipalpis females fed on rabbits immunized with sandfly extracts and bites (Mantel-Haenszel test).

\begin{tabular}{|c|c|c|}
\hline Extracts & Nulliparous & Parous \\
\hline $\mathrm{gb} X$ control & $0.3 *$ & $0.7 *$ \\
\hline gs X control & $6.0^{*}$ & $0.3 *$ \\
\hline $\mathrm{cb} X$ control & $2.6^{*}$ & $24.1 * *$ \\
\hline cs X control & $3.3^{*}$ & $8.81 *$ \\
\hline bite $\mathrm{X}$ control & $11.5 * *$ & $34.5 * *$ \\
\hline $\mathrm{gb} \times \mathrm{cb}$ & $4.1 *$ & $54.2 * *$ \\
\hline $\mathrm{gb} \times \mathrm{gs}$ & $5.0 *$ & $2.57 *$ \\
\hline $\mathrm{gb} \times \mathrm{cs}$ & $0.9 *$ & $16.4 * *$ \\
\hline gb $\times$ bite & $27.7 * *$ & $42.7 * *$ \\
\hline $\mathrm{cb} \times \mathrm{gs}$ & $3.1 *$ & $36.8 * *$ \\
\hline $\mathrm{cb} \times \mathrm{cs}$ & $7.9 *$ & $14.7 *$ \\
\hline $\mathrm{cb} \times$ bite & $6.6^{*}$ & $6.4^{*}$ \\
\hline gs X cs & $0.5^{*}$ & $2.9 *$ \\
\hline gs $X$ bite & $35.0 * *$ & $45.7 * *$ \\
\hline cs $X$ bite & $33.5 * *$ & $18.6 * *$ \\
\hline
\end{tabular}

* significant

$* *$ not significant

salivary gland tissue demonstrated by ELISA tests in animals immunized with either bites or salivary gland (Ramasamy et al., 1988; Hatfield, 1988; Ramasamy et al., 1990; Ramasamy \& Ramasamy, 1990; Ramasamy et al., 1992; Almeida \& Billingsley, 1999).

Our studies showed no variation in relation to acceptance of feeding among immunized and control groups. Insects fed on all the groups indiscriminately. Similar results were seen with $P$. argentipes, which showed no differences when feeding on animals subjected to repeated bites (Ghosh \& Mukhopadhyay, 1998). Similarly, practically all the $P$. duboscqi females ingurgitated in their first exposure to hamsters immunized with different concentrations of sandfly extracts (Ingonga et al., 1996). A considerable variation in the duration of blood-feeding was displayed by $P$. duboscqi females kept in contact with the immunized animals for about $2 \mathrm{~h}$ (Ingonga et al., 1996). L. longipalpis females belonging to the experimental groups took a somewhat longer period to feed, from 1 and $2 \mathrm{~h}$, with more frequent interruptions, while the control group fed in a slightly shorter time of about 30-40 min.
Ghosh \& Mukhopadhyay (1998) reported that the mortality of $P$. argentipes prior to oviposition increased progressively between the first and fifth exposure of hamsters to bites, though not at significant levels. Ingonga et al. (1996) observed that the mortality of $P$. duboscqi fed on hamsters immunized against different concentrations of gut and carcass increased in the first three days of evaluation in relation to the control group. The effect was more evident in the first feeding of females on hamsters immunized with gut. The mortality of females fed on hamsters immunized with carcass was more evident after the second feeding. Survival of $P$. duboscqi was monitored up to the sixth post-feeding day, and mortality was found to be higher in the group fed on hamsters immunized with gut extracts.

In our study, females exposed to repeated bites or immunized with GB showed the highest death rates. Also, when the mortality of nulliparous and parous females was compared, females without oviposition showed a higher rate of mortality within the experimental groups. This may be important from the standpoint of potential control of natural sandfly populations. 
A decrease in the number of eggs laid was seen in L. longipalpis females, when tissues of sandflies fed on blood were used in the immunizations. Since it is well known that blood acquisition is a necessary step for the formation of eggs, it is possible that these antibodies have an effect on molecules required for the good absorption of elements present in the blood meal, or for the processing of these components into eggs. Ramasamy et al., (1988) reported a reduction in the number of eggs laid by Aedes aegypti after feeding on rabbits immunized with different mosquito extracts (head-thorax, gut or abdomen) and on the fewer vitellogenic oocytes produced. These antibodies also effected the viability of the eggs laid, which was evidenced by a decrease in the F1 generation.

A lowered fecundity rate was also observed in Anopheles tesselatus fed on mice immunized with mosquito extracts (Srikrishnaraj et al., 1993). The same effect was observed in Ae. aegypti fed on guinea pigs immunized against mosquito carcass, but not when Culex tarsalis females were fed on the same animals, indicating antigen specificity (Sutherland \& Ewen, 1974). Almeida \& Billingsley (1998) fed An. stephensi on mice immunized with various mosquito tissues and evaluated the effect on survival and fecundity. Gut tissue had a pronounced effect on survival and fat body on egg laying.

The importance of anti-saliva antibodies was demonstrated by their interference in the development of Leishmania in the gut of the sandfly (Ghosh \& Mukhopadhyay, 1998). Also, it has recently been shown that bites of uninfected $P$. papatasi are capable of protecting mice against infection by L. major (Kamhawi et al., 2000).

Some interesting studies have contributed to the body of knowledge about $L$. longipalpis saliva. Antibody responses to salivary gland homogenates of L. longipalpis were investigated using sera of individuals from an endemic area of visceral leishmaniasis. Results suggest that sandfly saliva proteins could be relevant in epidemiological investigations (Barral et al., 2000, Gomes et al., 2002). Studies conducted by Melo et al. (2001) indicate that initial stages of Leishmania infection can be affected by L. longipalpis salivary gland lysates. Recently, a review of this sandfly vector provided important information about saliva compounds and properties (Soares \& Turco, 2003).
Since L. longipalpis females fed on rabbits exposed to sandfly bites presented lower fecundity and higher mortality than control groups, possible implications for disease transmission should be considered.

Variable results have been obtained in previous studies on the effect of anti-vector antibodies on various biological aspects of insects, and also on the success of parasite development (Jacobs-Lorena \& Lemos, 1995). Nevertheless, as mentioned repeatedly here in, most experiments showed detectable, albeit occasionally subtle effects. These promising results have led many authors to suggest the need for eventually identifying the molecules involved in these deleterious effects on insects. One of the reasons that led us to carry out the work described here was the lack of such studies on L. longipalpis, the main vector for visceral leishmaniasis in Brazil. Most of the references in this paper refer to many different species of mosquitoes, but very few involve two different species of Phlebotomus. The data obtained in this assay provide evidence, albeit discrete, indicating that anti-sandfly antibodies could affect some aspects of the biology of L. longipalpis. The effect on fecundity and mortality of L. longipalpis observed in females fed on rabbits immunized against GB and repeated bites suggests the need for the identification of relevant target molecules that might be responsible for these effects. We are currently also investigating the effect of these antibodies on the successful establishment of leishmania in the sandfly.

Acknowledgments - We are indebted to Dr. Denise Valle and André de Figueiredo Barbosa, MSc., from the Departamento de Entomologia/IOC/FIOCRUZ, for their critical suggestions. Thanks are also due to Dr. Reginaldo P. Brazil, from the Centro de Pesquisa René Rachou/FIOCRUZ, Dr. Ítalo Sherlock, Dr. Mittermeyer Galvão dos Reis and Mr. Antonio Carlos dos Santos, from the Centro de Pesquisa Gonçalo Moniz/FIOCRUZ, for their support in the field work. This work was supported by the Programa de Apoio à Pesquisa Estratégica-PAPES/FIOCRUZ and CNPq (Brazil).

\section{REFERENCES}

ALGER, N. E. \& CABRERA, E. J., 1972, An increase in death rate of Anopheles stephensi fed on rabbits immunized with mosquito antigen. Journal of Medical Entomology, 65: 65-168.

ALMEIDA, A. P. G. \& BILLINGSLEY, P. F., 1998, Induced immunity against the mosquito Anopheles stephensi Liston (Diptera: Culicidae): effects on mosquito survival 
and fecundity. International Journal of Parasitology, 28: 1721-1731.

ALMEIDA, A. P. G. \& BILLINGSLEY, P. F., 1999, Induced immunity against the mosquito Anopheles stephensi: reactivity characteristics of immune sera. Medical and Veterinary Entomology, 13: 53-64.

BARRAL, A., HONDA, E., CALDAS, A., COSTA, J., VINHAS, V., ROWTON, E. D., VALENZUELA, J. G., CHARLAB, R., BARRAL-NETO, M. \& RIBEIRO, J. M., 2000, Human immune response to sand fly salivary gland antigens: a useful epidemiological marker? American Journal of Tropical Medicine and Hygiene, 62: 740-745.

BELKAID, Y., KAMHAWI, S., MODI, G., VALENZUELA J., NOBEN-TRAUTH, N., ROWTON, E., RIBEIRO, J. \& SACKS, D. L., 1998, Development of a natural model of cutaneous leishmanisis: powerful effects of vector saliva and saliva preexposure on the long-term outcome of Leishmania major infection in the mouse ear dermis. Journal of Experimental Medicine, 188: 1941-1953.

CONSOLI, R. A. G. B. \& LOURENÇO DE OLIVEIRA, R., 1994, Controle químico e biológico: Perspectivas, pp. 155-159. In: Principais mosquitos de importância sanitária no Brasil. Editora Fiocruz.

GHOSH, K. N. \& MUKHOPADHYAY, J., 1998, The effect of anti-sandfly saliva antibodies on Phlebotomus argentipes and Leishmania donovani. International Journal of Parasitology, 28: 275-281.

GOMES, R. B., BRODSKYN, C., DE OLIVEIRA, C. I., COSTA, J., MIRANDA J. C., CALDAS A., VALENZUELA J. G., BARRAL-NETO M. \& BARRAL, A., 2002, Seroconversion against Lutzomyia longipalpis saliva concurrent with develompment of anti-Leishmania chagasi delayed-type hypersensitivity. Journal of Infectious Diseases, 186: 1530-1534.

HATFIELD, P. R., 1988, Anti-mosquito antibodies and their effects on feeding, fecundity, and mortality of Aedes aegypti. Medical and Veterinary Entomology, 2: 331-338.

INGONGA, P., MBATII, P. A., ANJILI, C. O., MUTANI, A., WISHITEMI, S. O., ROBERT, L. L. \& GITHURE, J. I., 1996, The effect of immune sera from hamsters immunized with sandfly gut and whole body extract antigens on the fecundity and mortality of Phlebotomus dubosqi (Diptera: Psychodidae). Acta Tropica, 60: 269-279.

JACOBS-LORENA, M. \& LEMOS, F. J. A., 1995, Immunological strategies for control of insect disease vectors: a critical assessment. Parasitology Today, 11: 144-147.

KAMHAWI, S., BELKAID, Y., MODI, G., ROWTON, E. \& SACKS, D., 2000, Protection against cutaneous leishmanisis resulting from bites of uninfected sand flies. Science, 290: 1351-1354.

LAL, A. A., SCHRIEFER, M. E., SACCI, J. B., GOLDMAN, I. F., LOUIS-WILEMAN, V., COLLINS, W. E. \& AZAZ, A. F., 1994, Inhibition of malaria parasite development in mosquitoes by anti-mosquito-midgut antibodies. Infection and Immunity, 67: 316-318.

LAEMMLI, U. K., 1970, Clevage of structural proteins during the assembly of the head of bacteriophage T4. Nature, 227: 680-685.
MELO, M. N., WILLIAMS, P. \& TAFURI, W. L., 2001, Influence of lysates of the salivary glands of Lutzomyia longipalpis on the development of a Leishmania major-like parasite in the skin of the golden hamster. Annals Tropical of Medicine and Parasitology, 95: 59-68.

MODI, G. B. \& TESH, R. B., 1983, A simple technique for mass rearing Lutzomyia longipalpis and Phlebotomus papatasi (Diptera: Psychodidae) in the laboratory. Journal of Medical Entomology, 20: 568-569.

PATARRoYO, J. H., PORTELA, R. W., DE CASTRO, R., PIMENTEL, J. C., GUZMAN, F., PATARROYO, M. E., VARGAS, M. I., PRATES, A. A. \& MENDES, M. A., 2002, Immunization of cattle with synthetic peptides derived from the Boophilus microplus gut protein (Bm86).Vet. Immunol. Immunopathol., 88: 163-172.

RAMASAMY, M. S., RAMASAMY, R., KAY, B. H. \& KIDSON, C., 1988, Anti-mosquito antibodies decrease the reproductive capacity of Aedes aegypti. Medical and Veterinary Entomology, 2: 87-93.

RAMASAMY, M., SANDS, M., KAY, B. H., FANNING, I. D., LAWRENCE, G. W. \& RAMASAMY, R., 1990, Antimosquito antibodies reduce the susceptibility of Aedes aegypti to arbovirus infection. Medical and Veterinary Entomology, 4: 49-55.

RAMASAMY, M. \& RAMASAMY, R., 1990, Effect of anti-mosquito antibodies on the infectivity of the rodent malaria parasite Plasmodium berghei to Anopheles farauti. Medical and Veterinary Entomology, 4: 161-166.

RAMASAMY, M. S., SRIKRISHNARAJ, K. A., WIKEOONE, S., JESUTHASAN, L. S. B. \& RAMASAMY, R., 1992, Host immunity to mosquitoes: Effect of antimosquito antibodies on Anopheles tesselatus and Culex quynquefasciatus (Diptera: Culicidae). Journal of Medical Entomology, 4: 934-938.

SOARES, R. P. \& TURCO S. J, 2003, Lutzomyia longipalpis (Diptera: Psychodidae: Phlebotominae): a review. Anais da Academia Brasileira de Ciências, 75(3): 301-330.

SRIKRISHNARAJ, K. A., RAMASAMY, R. \& RAMASAMY, M. S., 1993, Fecundity of Anopheles tesselatus reduced by the ingestion of murine anti-mosquito antibodies. Medical and Veterinary Entomology, 7: 66-68.

SUTHERLAND, G. B. \& EWEN, A. B., 1974, Fecundity decrease in mosquitoes ingesting blood from specifically sensitized mammals. Journal of Insect Physiology, 20: 655-660.

TRAGER, W., 1939, Acquired immunity to ticks. Journal of Parasitology, 25: 57-81.

WERMELINGER, E. D., RANGEL, E. F., SOUZA, N. A. \& BARBOSA, A. F., 1987, A practical method for mass breeding of sandflies in the laboratory: Lutzomyia intermedia (Lutz \& Neiva, 1912) and Lutzomyia longipalpis (Lutz \& Neiva, 1912) (Diptera: Psychodidae: Phlebotominae). Memórias do Instituto Oswaldo Cruz, 82: 441-442.

WIKEL, S. K., 1982, Immune responses to arthropods end their products. Annual Review of Entomology, 27: 21-48. 